\title{
Archipel
}

ARCHIPEL Études interdisciplinaires sur le monde insulindien

$88 \mid 2014$

Varia

\section{Defending the monarchy: The Malay rulers and the making of the Malayan constitution, 1956-1957}

Défendre la monarchie : les dirigeants malais et l'élaboration de la constitution de la Malaya, 1956-1957

Joseph M. Fernando

\section{OpenEdition}

\section{Journals}

Édition électronique

URL : https://journals.openedition.org/archipel/528

DOI : $10.4000 /$ archipel. 528

ISSN : 2104-3655

Éditeur

Association Archipel

Édition imprimée

Date de publication : 10 October 2014

Pagination : 149-167

ISBN : 978-2-910513-71-9

ISSN : 0044-8613

\section{Référence électronique}

Joseph M. Fernando, « Defending the monarchy: The Malay rulers and the making of the Malayan

constitution, 1956-1957 », Archipel [En ligne], 88 | 2014, mis en ligne le 10 septembre 2017, consulté le 21 septembre 2021. URL : http://journals.openedition.org/archipel/528 ; DOl : https://doi.org/

$10.4000 /$ archipel. 528 
JOSEPH M. FERNANDO ${ }^{1}$

\section{Defending the monarchy: The Malay rulers and the making of the Malayan constitution, 1956-1957}

The institution of constitutional monarchy remains one of the core institutions in the system of parliamentary democracy practised in Malaysia. The hereditary Malay rulers in nine states continue to wield considerable influence on the political system through a range of powers conferred by the federal constitution. Few, however, may be aware that the Malay rulers fought a pitched battle during the drafting of the Malayan independence constitution between 1956 and 1957 to safeguard their constitutional status and powers. The primary constitutional documents reveal that the rulers challenged strongly the very limited provisions made in the Reid draft constitution in regard to their constitutional powers, the role and function of the Conference of Rulers, and the limited financial powers accorded to the state governments. The rulers redefined their role and position from that provided in the Reid draft constitution and emerged considerably stronger in the administration of the state, and on matters of national importance. While the rulers accepted the basic premise of their position as "constitutional sovereigns" in the 1957 Malayan federal constitution (and state constitutions) as agreed at the London conference in January 1956, they were able to enhance their constitutional status significantly from the limited powers provided in the Reid draft constitution.

This intense contestation between the Malay rulers and the ruling Alliance Party on the former's constitutional position during the framing of the Malayan federal constitution between 1956 and 1957 has not received adequate attention. Only two studies have some historical discussion on the constitutional position of the rulers, albeit in a broader sense. The first, by Simon Smith, discusses the constitutional

1. Department of History, Faculty of Arts and Social Sciences, University of Malaya, Kuala Lumpur, Malaysia. 
deliberations involving the rulers as part of a broader examination of the relationship between the British government and the Malay rulers since British intervention in the Malay states in $1874 .^{2}$ This work, however, does not examine in sufficient depth the constitutional contestation in 1956 and 1957 on the role and power of the constitutional monarchs because of its much wider focus. Smith, while acknowledging that the rulers envisaged a bigger role in the administration of the state than the Reid commission or the Alliance, has not developed significantly the outcome of this element in the new constitution. ${ }^{3}$ The second work, by Kobkua Suwannathat-Pian, has suggested that the Malay rulers played a "supporting and subservient role" to the United Malays National Organisation (UMNO) and the Alliance Party from 1955 and that the 1957 Malayan constitution "underwrites such a conclusion." Kobkua's work, which has not examined the primary constitutional documents adequately, has contended that this period saw the institution of monarchy playing a "distant second fiddle" against UMNO during the drafting of the constitution. ${ }^{5}$ This article will show that contrary to this argument, the rulers enhanced their constitutional role considerably after making strong representations on the role and powers of the constitutional monarchs during the later Working Party stages of the constitutional deliberations. Fernando's work on the framing of the Malayan constitution has some discussion on the debates between the Alliance Party and the rulers on the latter's constitutional role but does not examine the subject in depth because of its broader focus. ${ }^{6}$ In addition, some legal studies discuss the powers of the rulers under the federal constitution from a strictly constitutional law perspective and are largely focused on the post-independence period, drawing mainly from a literal reading of the constitution and with reference to case studies of court judgements and some secondary sources. ${ }^{7}$ These studies invariably do not shed sufficient historical insight into the constitution-making process which shaped the powers and status of the institution of monarchy in independent Malaya. It is important to understand the

2. Simon C. Smith, British Relations with the Malay Rulers from Decentralization to Malayan Independence, 1930-1957, Kuala Lumpur: Oxford University Press, 1995, pp. 149-160.

3. Ibid., p. 152.

4. Kobkua Suwannathat-Pian, Palace, Political Party and Power: A story of the socio-political development of Malay kingship, Singapore: National University of Singapore, 2011, p. 315.

5. Ibid., p. 303.

6. Joseph M. Fernando, The making of the Malayan constitution, Kuala Lumpur: Malaysian Branch of Royal Asiatic Society, 2002, p. 117 and pp. 169-170.

7. These legalistic studies, mainly on constitutional law, include the work of R.H. Hickling, An introduction to the Federal constitution, Kuala Lumpur: Federation of Malaya Information Services, 1960, pp. 27-32; Harry E. Groves, The constitution of Malaysia, Singapore: Malaysia Publications, 1964, pp. 38-59; Mohamed Suffian, H.P. Lee and F.A. Trindade (eds), The constitution of Malaysia: Its Development, 1957-1977, Kuala Lumpur: Oxford University Press, 1978, pp. 101-122; F.A. Trindade and H.P. Lee (eds), The constitution of Malaysia: Further Perspectives and Developments, Singapore: Oxford University Press, 1986, pp. 76-91; Andrew Harding, The constitution of Malaysia, Oxford: Hart Publishing, 2012, pp. 113-132; and Abdul Aziz Bari, Malaysian constitution: A critical introduction, Kuala Lumpur: The Other Press, pp. 51-65. 
debates and agreements reached during the constitutional deliberations to obtain a deeper appreciation of the position of constitutional monarchy in the 1957 federal constitution. This article first provides some background to the evolution of the monarchy in Malaya and then examines closely several areas where the rulers contested strongly the provisions in the Reid draft constitution relating to their status and powers. This article shows that the rulers, contrary to claims that they played second fiddle during the drafting of the constitution, in fact put up much resistance to any further erosion of their sovereign powers and were able to redeem their constitutional powers considerably following strong arguments presented in the Working Party which reviewed the Reid draft constitution.

\section{Evolution of constitutional monarchy in Malaya}

British intervention in Malaya in the $19^{\text {th }}$ century reduced considerably the powers of the Malay rulers in the nine states with a hereditary ruler after the appointment of a British Resident or British Adviser. ${ }^{8}$ The British control of the mainland Malay states began with the Pangkor Treaty signed in 1874 with the ruler of Perak which provided for the appointment of a British Resident in the state. Following this, similar agreements were signed with the states of Selangor, Negri Sembilan and Pahang. ${ }^{9}$ In these four states, which became the Federated Malay States (FMS) in 1895 with a central legislature, the rulers were to accept the advice of the British Residents on all matters other than the Muslim religion and Malay customs. In the Federated Malay States, while the rulers continued to enjoy sovereignty, the British Resident was the de facto chief executive in each state. ${ }^{10}$ The British Advisers in the Unfederated Malay States (UMS) comprising Kedah, Perlis, Kelantan, Terengganu and Johore, on the other hand, had lesser powers but were still influential. ${ }^{11}$ The rulers nevertheless retained their sovereignty and all legislation passed by the central legislature of the FMS or the state councils of the respective states required their approval. During the Japanese occupation of Malaya between 1941 and 1945, the rulers were deprived of all their powers and merely had a nominal advisory role in the administration of the state. ${ }^{12}$

On re-occupation of Malaya by the British in 1945, the rulers were reinstated to their traditional position as head of state. Their powers, however, were soon to undergo radical change with the introduction of political reforms in Malaya by the Colonial Office. The Malayan Union scheme, introduced in 1946 to create a unitary state with a stronger and more efficient administration and defence, transferred the sovereignty of

8. Richard Winstedt, A History of Malaya, Kuala Lumpur: Marican and Sons Ltd., 1968, pp. 224-240.

9. See Simon Smith, British relations with the Malay rulers, pp. 4-7.

10. Ibid., p. 15.

11. Suwannathat-Pian, Palace, Political Party and Power, pp. 60-86.

12. Paul Kratoska, The Japanese occupation of Malaya: A social and economic history, St Leonards: Allen and Unwin, 1998, pp. 67-71. 
the Malay rulers to the British Crown. But following strong protests from the Malays, the scheme was discontinued and replaced by the Federation of Malaya Agreement in 1948. ${ }^{13}$ Under the new agreement, the rulers regained most of their powers but became constitutional monarchs. The 1948 federation agreement converted the Malay rulers into constitutional monarchs formally. The agreement, however, did not define clearly the parameters of the powers of the rulers and while it worked considerably well in the pre-independent period under the leadership of the High Commissioner, independence required a more precise definition of the status and position of the rulers with the full functioning of parliamentary democracy and party politics. The Reid constitutional commission invariably had to consider very carefully the constitutional position and status of the Malay rulers in a fully-elected civil government.

\section{Defining the parameters of the constitutional monarchy}

The Reid commission, which drafted the new constitution of the Federation of Malaya between June 1956 and February 1957, was required by their terms of reference to ensure "the safeguarding of the position and prestige of Their Highnesses as constitutional Rulers of their respective States."14 The commission was also required to provide for a constitutional head of state or Paramount Ruler for the whole federation. Invariably, it was tasked to define the parameters of the constitutional monarchy more precisely. While the concept of constitutional monarchy was already observed in practice with the coming into force of the Federation of Malaya Agreement on 1 February 1948, the legal boundaries of this concept were not clear. Moreover, as the British High Commissioner was the chief executive of the federation, there seemed no real need to define more precisely the powers of the constitutional monarchs. The High Commissioner was able to moderate the acceptance of federal policies and programs in the states by the rulers and their implementation with his regular consultations with the Conference of Rulers and the chief ministers of the states. The situation, however, would be altered considerably after independence with fully-elected legislatures at the state and national levels and this required the commission to define more clearly the parameters of constitutional monarchy.

The challenge facing the commission in determining the constitutional position of the rulers is evident in Sir Ivor Jennings' paper on the changes implied in the commission's terms of reference on the monarchy. ${ }^{15}$ Jennings in his paper observed

13. See A.J. Stockwell, British policy and Malay politics during the Malayan Union experiment, Kuala Lumpur: Malaysian Branch of the Royal Asiatic Society, 1979, pp. 17-107. See also Albert Lau, The Malayan Union controversy, 1942-1948, Singapore: Oxford University Press, 1991, pp. 28-240.

14. Report of the Federation of Malaya Constitutional Commission 1957, London: Her Majesty's Stationery Office, Colonial No. 330, p. 6.

15. The constitutional commission was chaired by Lord Reid, a Lord of Appeal in the Ordinary in the House of Lords. The other members of the commission were Sir Ivor Jennings, Master of Trinity Hall, Cambridge University; Sir William McKell, a former Governor-General of Australia; Chief Justice B. Malik of the Allahabad High Court and Justice Abdul Hamid of the West Pakistan High Court. 
that while the position and prestige of the rulers must be safeguarded vis-avis succession to the thrones, the Civil List, and so forth as provided in the state constitutions, they "must be so amended to make Their Highnesses and their heirs and successors constitutional rulers." 16 In the then existing arrangement, the executive power was vested in "His Highness in Council" and this meant the rulers acting after consultation with the state executive council but not necessarily in accordance with the advice of such council. ${ }^{17}$ Jennings felt this was constitutionally inconsistent with the practices of having an elected legislature in the states where he felt that power should rest with the elected representatives:

Indeed, the very concept of His Highness in Council, except as a formal body like the Queen in Council in the United Kingdom, or the Governor-General in Council in Canada, is inconsistent with constitutional government. ${ }^{18}$

In relation to the position of the Yang di-Pertuan Agong, the supreme head of state, Jennings observed that he would not exercise the discretionary powers of the High Commissioner but would act on the advice of the government of the federation. ${ }^{19}$ The High Commissioner had considerable personal powers under the federation government, including the power of veto over legislation passed by the federal legislative council. The Reid commission agreed with Jennings on the position of the rulers as constitutional monarchs and the need to reaffirm this element clearly in the new constitution.

The Reid commission felt the rulers should not be involved in politics or be given much political functions or powers in keeping with the general understanding of the concept of constitutional monarchy based on the British model. ${ }^{20}$ The commission expected the rulers, as constitutional monarchs, to act on the advice of the Prime Minister and the Cabinet (at the federal level), and the ChiefMinister (at the state level), with the exception of a few subject matters where the rulers had some discretionary constitutional powers. In the draft constitution, the commission provided that the supreme head of state, the Yang di-Pertuan Agong (Article 35), should act on the advice of the Prime Minister and the Cabinet. ${ }^{21}$ The exception to this was in the

16. Paper by Sir Ivor Jennings titled, "Constitutional changes implicit in the terms of reference." 23 Aug. 1956, p. 2, CO 889/2, C.C. 2000/15.

17. Ibid., p. 3 .

18. Ibid., p. 3.

19. Ibid., p. 4.

20. See Summary record of $33^{\text {rd }}$ meeting of constitutional commission, 17 Sept. 1956, pp. 1-2, CO 889/1 (36). See also Summary record of $34^{\text {th }}$ meeting of constitutional commission, 26 Sept. 1956, pp. 1-2, CO 889/1 (37).

21. Report of the Federation of Malaya constitutional commission 1957, pp. 12-13. Article 35 states: "In the exercise of his functions under this Constitution and the law, the Yang di-Pertuan Besar [later renamed Yang di-Pertuan Agong] shall act in accordance with the advice of the Cabinet, the Prime Minister, or the appropriate Minister, as the case may be, except in the cases specified below where he may act in his discretion, namely - (a) the appointment of a Prime Minister, (b) the dissolution of Parliament, and (c) the 
appointment of the Prime Minister and the dissolution of parliament, where the head of state could act in his discretion. In other words, the Yang di-Pertuan Agong could use his discretion to appoint a person who he believed commanded support of the majority in parliament as Prime Minister. And, secondly, he could use his discretion and refuse to accept the advice of the Prime Minister to dissolve parliament in the event the ruling party does not command a majority. The Yang di-Pertuan Agong (Article 34) was, further, entitled to obtain from the federal government information relating to the administration of the federation. ${ }^{22}$ This was also the intention of the Alliance which emphasised that the rulers should be above politics as evident in their memorandum and oral evidence given to the commission. ${ }^{23}$ On the role of the Conference of Rulers, for example, the Alliance leader and Chief Minister Tunku Abdul Rahman, himself a member of a royal household, told the commission when asked if the former should have any political function:

They can discuss matters concerning the Muslim religion and Malay custom, but they cannot discuss any matters of administration unless they want to interest themselves in such matters: but their decision will not be binding. They will be constitutional rulers. ${ }^{24}$

In line with their role as constitutional monarchs, the commission also recommended that certain provisions be inserted in the state constitutions (Fifth Schedule, Article 1) which provided that in the exercise of his functions under the state constitution the ruler will act in accordance with the advice of the Mentri Besar (the chief minister) or state executive council. ${ }^{25}$

The rulers, however, envisaged considerably greater constitutional powers than the Alliance government or the Reid Commission had in mind. In the discussions with the constitutional commission, the rulers put up considerable resistance to any attempt to diminish their powers. ${ }^{26}$ Their effort, however, was not very successful at

exercise of his right to obtain information in accordance with the provisions of Article 34."

22. Report of the Federation of Malaya constitutional commission 1957, p. 13. Article 34 reads: "The Yang di-Pertuan Besar shall be entitled to obtain from any other part of the Federal Government such information relating to the administration of the affairs of the Federation as he may call for."

23. CO 889/6 (2), Summary record of hearing of the Alliance Party, 27 Sept. 1956, p. 2. See also verbatim record of Alliance hearing at CO 889/6 (3), 27 Sept. 1956, pp. 5-6.

24. See also verbatim record of Alliance hearing at CO 889/6 (3), 27 Sept. 1956, p. 6.

25. Report of the Federation of Malaya constitutional commission 1957, p. 71. Article 1 of the Fifth Schedule to be inserted into the state constitutions stated: "In the exercise of his functions under this Constitution and the law the Ruler shall act in accordance with the advice of the Executive Council or of the Mentri Besar, as the case may be, save that in respect of - (a) the appointment of a Mentri Besar; (b) the dissolution of the State Legislature, and; (c) the exercise of his right under this Constitution to obtain information relating to the administration of the affairs of the State, he may act in his discretion."

26. Verbatim report of Hearing of counsel on behalf Their Highnesses the Rulers, 14-15 Sept. 1956, CO 889/1 (32), C.C. 2014. Lawson was assisted by M.G. Neal. The other rulers' representative were Tuan Haji Abdul Wahab bin Abdul Aziz, Dato' Panglima Gantang, the Mentri Besar of Perak; Shamsudin bin Nain, Mentri Besar of Negri Sembilan; Mohd. Suffian bin Hashim, State Secretary of Pahang ; Raja Zainal Abidin bin Raja Haji Tachik; Raja Haji Ahmad bin Raja Indut, Mentri Besar of Perlis; Dato' Kamaruddin bin Haji Idris, Mentri Besar of Terengganu; Tuan Haji Mustapha Albakri bin 
this stage as the draft constitution accommodated very little of the Rulers' demands contained in their memorandum and in the lengthy submissions made by their counsel during the hearing given by the commission. Nevertheless, the rulers' counsel took up the issues strongly at the Working Party stage when the Reid draft constitution was reviewed by a committee comprising the High Commissioner Sir Donald MacGillivray, the federation Attorney-General T.V.A. Brodie and the representatives of the Alliance and the rulers. After a hard-fought battle and some tense moments, which included a boycott of the Working Party meetings launched by the rulers' representatives at one stage, the rulers were able to add considerably more powers to their position then provided in the original Reid draft constitution. They evidently did not play second fiddle to the Alliance Party during the constitutional deliberations. There were four main areas where the rulers put up strong resistance to safeguard their prestige, status and powers and were able to restore some of their powers. These were first, in respect of the meaning of the term 'constitutional monarchy'; second, their personal powers in relation to appointments in the state legislatures; third, the role and functions of the Conference of Rulers; and, fourth, the financial powers of the state vis-a-vis the federal government.

The rulers' counsel, Neil Lawson, was the main proponent of a wider constitutional role for the nine monarchs during the constitutional debates. He developed strong arguments in the Working Party to demand the restoration of some of the discretionary powers of the rulers and the Conference of Rulers provided in the 1948 federation agreement. The main thrust of Lawson's argument was that the rulers had traditionally possessed considerable discretionary powers in appointments to the state executive council and office of Mentri Besar, on some aspects of administration including on finance, and in respect of any territorial changes. ${ }^{27} \mathrm{He}$ felt that these discretionary powers should continue to be retained by the nine monarchs. Lawson further argued strongly that the Conference of Rulers should have a 'consultative and advisory' role as provided in the federation agreement. ${ }^{28}$ This was very much against the general position of the Reid commission, as articulated clearly by Jennings (see above), which felt that in a fully functioning democracy, the role of the rulers should be nominal and the directly elected legislature should be the main authority. The Alliance leader Tunku and High Commissioner MacGillivray were in agreement with the Reid commission and expressed their reservations in the Working Party over the demands made by Lawson. ${ }^{29}$ There was considerable debate and further

Haji Hassan, Keeper of the Rulers' Seal; Tengku Mohamed Hamzah bin Tengku Zainal Abidin, Mentri Besar of Kelantan; Abdul Aziz bin Haji Abdul Majid, Mentri Besar of Selangor; and Azmi bin Haji Mohamed, representative of the Mentri Besar of Kedah.

27. Verbatim report of Hearing of counsel on behalf Their Highnesses the Rulers, 14-15 Sept. 1956, p. 7, CO 889/1 (32), C.C. 2014.

28. Fernando, The making of the Malayan constitution, p. 117.

29. Minutes of first Working Party meeting, 22 Feb 1957, CO 941/85. See also Fernando, op. cit., pp. 169-170. 
compromises were necessary before an agreement was reached. We now examine these areas of debate.

\section{Defining the constitutional monarchy}

The constitutional documents indicate that the rulers' understanding of the term "constitutional monarchy" in relation to their position and powers in the respective states was much broader than that of the constitutional commission or the Alliance. In their memorandum to the Reid commission, the rulers' stated unequivocally that while they accepted the decisions made at the London conference in January 1956 to establish a self-governing independent state with a strong central government, they wanted to ensure that their prestige and status as constitutional monarchs were safeguarded in the new constitution without further erosion of their powers. ${ }^{30}$ The rulers' memorandum stated:

Their Highnesses while accepting the status of Constitutional Sovereigns and the necessity of such limitations being imposed upon the present manifestations of Their sovereignty as are necessary to give effect to the agreed decisions of the London conference, consider that it would be inconsistent with the safeguarding of Their prestige and position to accept other or further limitations. ${ }^{31}$

Two issues which the rulers regarded as the most important manifestations of their sovereignty was their personal position as titular founts of the temporal and spiritual authority in their respective territories, and the ties of personal allegiance between the rulers and their subjects in the states. ${ }^{32}$ The rulers' counsel argued that the existing position on the sovereignty of the rulers was that they could promulgate a new constitution for their respective states unhindered by any provision in their existing constitutions or the federal agreement. ${ }^{33}$ And it was up to the rulers to decide the date when they would assume a "truly constitutional position," as envisaged with the changes made in the new constitution. ${ }^{34}$ This was a reminder to the commission that while the rulers accepted their position as constitutional monarch in the new constitution, the eventual form would have to be decided in negotiations with the Alliance government and Her Majesty's Government. ${ }^{35}$ On their ties with their subjects, the rulers emphasised that there was a special bond of loyalty and that this was strongly evident in the fact that 8,000 people applied to be registered as subjects

30. Rulers' memorandum to the Reid commission, 12 September 1956, pp. 4-5, CO 889/6 (22).

31. Ibid., p. 5.

32. Verbatim report of Hearing of counsel on behalf Their Highnesses the Rulers, 14-15 Sept. 1956, p. 7, CO 889/1 (32), C.C. 2014. See also Rulers'memorandum to the Reid commission, 12 September 1956, p. 4, CO 889/6 (22).

33. Verbatim report of Hearing of counsel on behalf Their Highnesses the Rulers, 14-15 Sept. 1956, p. 7, CO 889/1 (32), C.C. 2014.

34. Ibid., p. 7.

35. Ibid., p. 8. 
of the rulers as against only 150 who applied for federal citizenship in $1955 .{ }^{36}$ "They suggest that there is a very strong feeling of loyalty to the Ruler of the State in which you live and work," said Lawson. ${ }^{37}$

There was an interesting debate during the hearing given by the Reid commission to the representatives of the rulers on the interpretation of the position and powers of the constitutional sovereign. The rulers' counsel argued that a constitutional sovereign meant a ruler who exercised his sovereignty in accordance with the provisions of a constitution which had force of law within his territory. ${ }^{38}$ That is, the sovereign would rule in accordance with the machinery of the state, a popularly elected state legislature that would decide on laws to be passed and financial control. ${ }^{39}$ The rulers accepted the role of constitutional sovereign in the temporal sphere but would not concede anything in the spiritual sphere. ${ }^{40}$ This point was not lost on the constitutional commission. This is evident from the fact that the Reid commission did not insert a provision to make Islam the official religion of the federation, as requested by the Alliance Party, on the grounds that the rulers had indicated clearly in their submissions that such a provision would go against their position as head of the Muslim faith in their own states. ${ }^{41}$ Matters related to the Muslim faith had always been under the jurisdiction of the Malay rulers. ${ }^{42}$ Further, in relation to the sovereignty, the rulers wanted the Council of State, headed by the ruler, to continue to have financial control at least in the interim period before the state legislatures were fully elected and not the elected State Executive Council. Counsel for the rulers pointed out to the commission that in some states control of finances was constitutionally vested in the Council of State and not the State Executive Council. ${ }^{43}$ The rulers' counsel pointed out, for example, that under Clause 24 of Part II of the Perak constitution the Council of State was vested with the financial powers. ${ }^{44}$ The rulers clearly had a considerably different conception of constitutional monarchy in the states than the commission and made a strong effort to retain its main elements. The commission, however, was not fully persuaded by the rulers' arguments and largely provided for the conventional understanding of constitutional monarchy based on the British model in the draft constitution. The Reid draft constitution thus provided for the dissolution of the Council of State on 1 January 1959 when elections in that year would pave the way for fully-elected state

36. Ibid., p. 7. The number of people who applied for naturalization as subjects of the rulers was 33,500 in 1955 while those who applied for naturalization as federal citizens was only 550.

37. Ibid., p. 7.

38. Ibid., p. 7.

39. Ibid., pp. 8-9.

40. Ibid., p. 8.

41. Report of the Federation of Malaya constitutional commission 1957, p. 73.

42. Simon Smith, British relations with the Malay rulers, pp. 15-16.

43. Verbatim report of Hearing of counsel on behalf Their Highnesses the Rulers, 14-15 Sept. 1956, p. 9, See CO 889/1 (32), C.C. 2014.

44. Ibid., p. 9. 
legislatures.$^{45}$ The rulers, as we will see below, objected to the recommendations of the Reid commission and sought a wider role.

\section{The Rulers and the selection of appointees in the state administration}

An area where the rulers sought a bigger role for the constitutional sovereign was in the appointments to the state legislature and administration. The rulers wanted discretionary powers to appoint the Mentri Besar, members of the state executive council and representation for special interests. ${ }^{46}$ The rulers felt they should be able to select the Mentri Besar and appoint members to the state executive council, including from outside the state legislature. While the rulers accepted that the machinery of government, including finance, would be run by representatives in the legislature elected by the people, they sought a bigger role for the state executive council which could include nominated officials, possibly even a nominated Mentri Besar. The commission, however, thought the appointment of nominated officials would go against the notion of responsible elected government where power lay in the hands of elected representatives. They felt that the Mentri Besar should be an elected one responsible to the electorate. ${ }^{47}$ The rulers' counsel Lawson attempted to make a case for the right of the rulers' to select members of the state executive council from outside the elected members in the state legislatures. He did not think this would be unconstitutional and argued that officials of the executive council could sometimes have their ears closer to the ground than the elected representatives and be better placed to advice the monarch. ${ }^{48}$

Lawson developed an argument to suggest that it was a common convention in "constitutional monarchies" for the Mentri Besar to be chosen by the head of state. ${ }^{49}$ The commission, however, was clearly not in favour of the Mentri Besar being selected by the ruler, and possibly from outside the elected members in the state legislature. They thought this was not practicable in a parliamentary democracy. Justice Abdul Hamid, a member of the commission, cited a hypothetical case where a Mentri Besar was appointed by the ruler but who then did not enjoy the confidence of the legislative assembly. ${ }^{50}$ Would such appointment be cancelled and would that provide for responsible government, he asked. ${ }^{51}$ Lawson attempted to justify

45. Report of the Federation of Malaya constitutional commission 1957, p. 77.

46. Verbatim report of Hearing of counsel on behalf Their Highnesses the Rulers, 14-15 Sept. 1956, pp. 9-12, CO 889/1 (32), C.C. 2014.

47. Verbatim report of Hearing of counsel on behalf Their Highnesses the Rulers, 14-15 Sept. 1956, p. 10, CO 889/1 (32), C.C. 2014. See also Summary record of $31^{\text {st }}$ meeting of constitutional commission, 12 Sept. 1956, p. 2, CO 889/1 (34), C.C. 1000.

48. Verbatim report of Hearing of counsel on behalf Their Highnesses the Rulers, 14-15 Sept. 1956, p. 11, CO 889/1 (32), C.C. 2014.

49. Ibid., p. 12.

50. Ibid., p. 12.

51. Ibid., p. 12. 
his argument by drawing a parallel with the constitutional monarch in Britain. He argued that the Queen could theoretically appoint him (Lawson) as Prime Minister if she wanted to: "Whether I should enjoy the confidence of the House of Commons is another question." 52 The rulers' counsel thought that the Mentri Besar would be a member of the state executive council but not necessarily an elected member of the state legislature. The new constitution, he argued, could provide for such an approach which would enable the ruler to select someone from the state executive council who may not be an elected member of the state legislature. ${ }^{53}$

The constitutional commission was not impressed with Lawson's argument. Reid thought that Lawson was suggesting a model which was a mix between the American and British system of government:

The American method is that Congress has security of tenure, and cannot by itself be in control of finance, etc. The executive arm are none of them members of Congress and they get along in their own way. I do not suppose you are suggesting that that picture should be adopted in Malaya? ${ }^{54}$

Lawson contended that the rulers felt that in the short term there was room for nominated members to lead the state executive council. ${ }^{55}$ Despite the strong argument raised by the rulers' counsel, in the draft constitution the Reid commission provided that the ruler of a state should appoint a Mentri Besar who was a member of the state legislature and who was likely to command the confidence of the majority in the legislature. ${ }^{56}$ This was in keeping with the general principles of the appointment of elected chief administrators in parliamentary democracies.

\section{The functions of the Conference of Rulers}

One of the areas where the rulers put up considerable resistance was the provisions related to the status and functions of the Conference of Rulers. The Reid commission did not make specific provisions in the draft constitution on the Conference of Rulers other than providing for the body to elect the Yang di-Pertuan Agong under Article 27. ${ }^{57}$ The Rulers recommended that the new Yang di-Pertuan Agong for the federation should be elected based on seniority in terms of the rulers' assent to their office. ${ }^{58}$ The commission agreed largely with the rulers' and their submission was adopted in the draft constitution. The status of the Conference of Rulers, however,

52. Ibid., p. 13.
53. Ibid., p. 12.
54. Ibid., p. 13.
55. Ibid., p. 14.

56. See Fifth Schedule of Reid Report, Part I, Article 2, p. 71. The Fifth Schedule includes articles which should be inserted in the state constitutions. See Summary record of the $33^{\text {rd }}$ meeting of the constitutional meeting, 17 Sept. 1956, pp. 1-3, CO 889/1 (36).

57. Report of the Federation of Malaya constitutional commission 1957, p. 11.

58. Verbatim report of Hearing of counsel on behalf Their Highnesses the Rulers, 14-15 Sept. 1956, pp. 26-28, CO 889/1 (32), C.C. 2014. See also Rulers Memorandum, pp. 8-10, CO 889/8. 
became a major issue of debate in the meeting of the Working Party. The Conference of Rulers had been formally convened since 1948 and met several times a year to discuss issues of national importance and was briefed by the High Commissioner. Prior to that, an informal meeting of the rulers in the Federated Malay States called the "Durbar" had met infrequently before the war to discuss issues of common importance to the four federated states.

The commission felt the Conference of Rulers could not play any constitutional part in the new constitution and merely provided for the body to elect the supreme head of state, the Yang di-Pertuan Agong. ${ }^{59}$ The Alliance had also told the commission that the rulers should be above politics. At the second meeting of the Working Party on 25 February 1957, the Rulers' representatives pointed out that there was no provision in the draft constitution for the establishment and constitution of the Conference of Rulers. They felt this could give rise to difficulties even in the limited functions conferred on the Conference of Rulers in Article 27 of the draft constitution. ${ }^{60}$ The rulers' wanted a number of additional powers to be conferred on the Conference of Rulers apart from the appointment of the Yang di-Pertuan Agong and his deputy. ${ }^{61}$ They felt the agreement of the Conference of Rulers should be sought in the appointment of the Chief Justice and judges of the Supreme Court, and heads of important commissions such as members of the Election Commission, Public Services Commission and Police Service Commission. ${ }^{62}$ It was argued, for example, that as the Election Commission in the discharge of its duties would be encroaching into the respective states and impinging on their territorial sovereignty, it was only right that they should have the right to concur in the appointment of such bodies. ${ }^{63}$ In addition, the rulers submitted that their consent should be sought in changes to the constitution on several matters which affected their sovereignty. These were, territorial changes affecting the states, changes which could affect the Muslim religion and Malay customs, amendments to the entrenched clauses (Article 157 on Malay special rights and Article 82 on Malay land reservations) in the constitution, changes affecting the status or powers of the states, and those affecting the privileges, position and dignities of the rulers. ${ }^{64}$ The rulers felt that changes related to these matters impinged on their sovereignty and they should have

59. Summary record of $33^{\text {rd }}$ meeting of constitutional commission, 17 Sept. 1956, p. 3, CO 889/1 (36). Summary record of the $34^{\text {th }}$ meeting of the constitutional commission, 26 Sept. 1956, p. 2, CO 889/1 (37).

60. Minutes of the Second meeting of the Working Party, 25 Feb. 1957, p. 1, CO 941/85.

61. Minutes of the Second meeting of the Working Party, 25 Feb. 1957, CO 941/85. See Note of Points to be raised by the Rulers Representatives, 25 Feb. 1957, p. 1, CO 941/85.

62. Minutes of the Second meeting of the Working Party, 25 Feb. 1957, CO 941/85. See Note of Points to be raised by the Rulers Representatives, 25 Feb. 1957, p. 1, CO 941/85.

63. Minutes of the Second meeting of the Working Party, 25 Feb. 1957, CO 941/85. See Note of Points to be raised by the Rulers Representatives, 25 Feb. 1957, p. 1, CO 941/85.

64. Minutes of the Second meeting of the Working Party, 25 Feb. 1957, CO 941/85. See Note of Points to be raised by the Rulers Representatives, 25 Feb. 1957, pp. 1-2, CO 941/85. 
the right "to give or withhold concurrence in such changes." 65

Further, the rulers wanted the Conference of Rulers to be consulted on changes to law affecting immigration, the concurrent list, power of parliament to legislate for states for uniformity (Article 70 of draft constitution), and the formula used to distribute federal funds to the states. ${ }^{66}$ The rulers were also unhappy that the draft constitution did not provide for the involvement of the rulers in the ceremony of affirmation of office of the Yang di-Pertuan Agong. The draft constitution merely provided for the newly-elected Yang di-Pertuan Agong to be sworn into office by taking an oath before the Chief Justice. The rulers' submitted that the Yang di-Pertuan Agong, the Supreme Head of State, should make an 'affirmation' of office and allegiance, and not an oath, and that this should be done in the presence of the Conference of Rulers and not merely before the Chief Justice. ${ }^{67}$ This was eventually provided in the new constitution.

An interesting discussion ensued in the meeting of the Working Party following the new demands made by the rulers' representatives. There was resistance from the Alliance and the High Commissioner MacGillivray to what was viewed as encroachment into politics by the rulers and which was deemed to conflict with their status as constitutional monarchs. MacGillivray thought that to give these additional functions to the rulers would bring them into the arena of politics and contradict one of the main recommendations of the Reid commission that the rulers should become constitutional rulers. ${ }^{68}$ The Alliance leader, Tunku Abdul Rahman, argued that to give these additional powers to the Conference of Rulers could be regarded as an encroachment on the powers of the Yang di-Pertuan Agong. ${ }^{69}$ MacGillivray pointed out that the existing functions of the Conference of Rulers were clearly understood and they met from time to time with the High Commissioner as representative of Her Majesty's Government to discuss matters of major importance. However, after independence this situation would have changed considerably as the Yang di-Pertuan Agong would be the representative of the rulers and there would be no High Commissioner and conferring these powers would impinge on the powers of the Yang di-Pertuan Agong, he argued. ${ }^{70}$

The rulers' representatives made some concessions in relation to the demands above but in the main held firm on their request for the concurrence of the Conference

65. Minutes of the Second meeting of the Working Party, 25 Feb. 1957, CO 941/85. See Note of Points to be raised by the Rulers Representatives, 25 Feb. 1957, p. 2, CO 941/85.

66. Minutes of the Second meeting of the Working Party, 25 Feb. 1957, CO 941/85. See Note of Points to be raised by the Rulers Representatives, 25 Feb. 1957, p. 2, CO 941/85.

67. Minutes of the second meeting of the Working Party, 25 Feb. 1957, CO 941/85. See Note of Points to be raised by the Rulers Representatives, 25 Feb. 1957, p. 2, CO 941/85.

68. Minutes of the second meeting of the Working Party, 25 Feb. 1957, p. 1, CO 941/85.

69. Ibid, p. 1.

70. Ibid, pp. 1-2. 
of Rulers in policy changes of national importance. ${ }^{71}$ After further discussions, the meeting agreed that the Conference of Rulers should be consulted on any changes affecting, "the privileges, position and dignities of Their Highnesses." 72 It was also agreed that every Yang di-Pertuan Agong, before entering upon his office, would take an oath of office and allegiance before the Conference of Rulers and the Chief Justice as set out in the First Schedule. ${ }^{73}$ This was significantly different from the recommendations of the Reid commission (Article 31) which recommended that the oath of office be taken before a Chief Justice. ${ }^{74}$

Eventually, the Alliance agreed to the other demands of the Rulers to be consulted on changes which affected their prestige and status, the territorial boundaries of the states and matters of major importance. Changes made to Part IV of the Reid draft constitution provided for the Conference of Rulers (Article 38 of the new constitution) to be officially constituted and consulted in the appointment of members of important commissions such as the Election Commission and the Police Service Commission; appointment of judges to the Supreme Court; and have the exclusive power in their respective states to grant pardons, reprieves, suspend or commute sentences passed by any court in respect of criminal offences..$^{75}$ This was a major victory for the Rulers as these provisions provided for a clearer role of the Conference of Rulers than that which had been recommended by the Reid Commission. It also provided stronger safeguards in the constitution to protect the status, position and privileges of the rulers.

\section{Federal-state relations and the question of financial autonomy}

The provisions relating to federal-state financial relations proved to be a major battleground between the rulers and the Alliance government. The rulers' fought hard to safeguard revenues traditionally distributed to the states under the 1948 federation agreement and sought greater constitutional guarantees to receive annual capitation and development grants, as of right, to provide for greater financial stability. The Alliance had to make several concessions to placate the demands of the rulers. The financial relations between the federal government and the states had evolved over time through trial and error and while it had worked fairly well there were considerable weaknesses and the commission sought to improve the existing financial arrangements and procedures. In the main, the commission sought to provide for a strong central government financially, in line with the terms of reference, by reserving most of the taxing powers to the federal government. At

71. Ibid, p. 2.

72. Ibid.,p. 2.

73. Minutes of the Second meeting of the Working Party, 25 Feb. 1957, p. 3, CO 941/85. See also Minutes of the Sixth meeting of the Working Party, 4 March 1957, p. 5, 941/85.

74. Report of the Federation of Malaya Constitutional Commission 1957, p. 12 and p. 62.

75. Minutes of the Sixth meeting of the Working Party, 4 March. 1957, pp. 5-6, CO 941/85. See Minutes of Eighth meeting of Working Party, 8 March 1957, pp. 4-6, CO 941/85. See also CO 941/87, Minutes of the Working Party. 
the same time, through an intricate set of grants guaranteed to the states annually from the federal government, the commission tried to provide for a greater degree of financial autonomy. The states, however, were not happy with the scheme of distribution of financial grants from the federal government and the sharing of levies from the export of tin and fought strongly to strengthen the states' financial position when the Working Party reviewed the recommendations of the Reid commission. Under the then existing financial arrangements, the states depended on federal grants to meet most of their annual expenses. In 1956, for example, the federal grants to the states amounted to $\$ 193$ million of the total $\$ 292$ million expenditure by the states. ${ }^{76}$ The federation paid most of the state expenditure on education, health services and the capital cost of drainage and irrigation. Under the system there was continued haggling each year between the federal government and the states to cover the latter's expenses and need for development funds. The commission recognised that the existing financial system while it was an improvement to the system in existence before 1954 could pose difficulties after independence when political parties would determine the finances. ${ }^{77}$

One major change that the commission made to ease the states' financial situation was to make education, medical and health services federal subjects. ${ }^{78}$ This meant that the states would not be burdened by these large expenses. Taxation, on the other hand, was a very contentious issue in the federal system and varied considerably in the Commonwealth and other federal systems. The majority in the commission did not want to extend the powers of the states to levy taxes which they felt would hamper the conduct of business on a national scale. ${ }^{79}$ The Reid commission provided for three main sources of grants to the states under Article 103. ${ }^{80}$ These were grantsin-aid of general revenue; the assignment of certain amounts from federal taxation, and licence fees and other fees of a local character. A simple formula was provided for the calculation of the grants-in-aid which drew on the provisions of the federation agreement. The commission recommended (Article 102) the establishment of a National Finance Council, comprising the Prime Minister, one other Minister and the Chief Ministers of the states to discuss matters of finance, including the state expenditures, capitation and other federal grants. ${ }^{81}$ But the recommendations of the commission did not rest well with the rulers and the states.

In the Working Party, the rulers' representative raised four issues in relation to federal-state financial relations: the taxing powers of the states; state revenues; state rights to grants; and the disposal of surpluses. Under the existing financial system the

76. Report of the Federation of Malaya Constitutional Commission 1957, p. 57.

77. Jennings' paper titled "Present financial arrangements," 29, Aug. 1956, p. 6, CO 889/2, C.C. 2000/3.

78. Report of the Federation of Malaya Constitutional Commission 1957, p. 60.

79. Ibid, p. 60.

80. Ibid., pp. 62-63.

81. Ibid., pp. 61-64. 
state surpluses reverted back to the federal government. ${ }^{82}$ The rulers' representatives noted that while the constitutional commission had intended that the states should have limited taxing powers, this was not reflected in the draft constitution. ${ }^{83}$ They also submitted that there should be an assignment to the states, as a matter of right, of revenues from the sources mentioned in the Third Schedule of the federation agreement. ${ }^{84}$ These included revenues from lands, mines and forests, revenues from licences, entertainment duty, fees in courts, fees and receipt from services provides by state governments, revenues from municipal and town boards, rents from state property and a share in surplus from the Malayan Currency Fund. ${ }^{85}$

The Alliance representatives in the Working Party did not accept these proposals as they felt the federation government should be free to make any adjustment necessary after consultation with the National Finance Council. ${ }^{86}$ The Alliance argued that revenues of the state should be authorised by Act of Parliament and that it would be difficult to lay down in the constitution that the states should receive any specific items of revenue. ${ }^{87}$ The rulers' representatives, however, pointed out that under the provisions of Article 156 of the draft constitution, the states would in fact continue to receive revenue during the transitional period from sources cited in the Third Schedule of the federation agreement, indicating that it would not be a great departure from the existing practice. ${ }^{88}$ Eventually, after further discussion, the Alliance agreed that the states should receive as of right, grants-in-aid, which was in line with the suggestion by the Reid commission. ${ }^{89}$ The Alliance, however, rejected the Rulers' proposal that a fixed percentage of the national revenue from customs import duties and excise should be allocated to the states as of right. ${ }^{90}$ A serious crisis ensued as a result of the Alliance's reluctance to meet some of the proposals on financial provisions made by the rulers' representatives. ${ }^{91}$ The rulers' representatives boycotted the seventeenth meeting of the Working Party on 9 April 1957 as a result. ${ }^{92}$

82. Minutes of Eleventh meeting of the Working Party, 12 March 1957, p. 1, CO 941/85.

83. Ibid., p. 1.

84. Eleventh meeting of the Working Party, 12 March 1957, pp. 1-2, CO 941/85. Part III of the federation agreement provides for 30 percent of customs duty on petrol to be divided by the states; a capitation grant for each adult who has attained the age of 20; a grant to cover all expenditure on education, medical and health services, and capital expenditure on drainage and irrigation works; a development grant determined by the High Commissioner for the states of Kelantan, Pahang, Perlis and Terengganu; and a transitional grant to ensure there was a surplus over expenditure, not exceeding $\$ 500,000$. See Memorandum on financial relations between federal government and states, 10 Oct. 1956, CO 889/7 (6).

85. Third Schedule, Federation of Malaya Agreement, 1948.

86. Eleventh meeting of the Working Party, 12 March 1957, p. 2, CO 941/85.

87. Ibid., p. 2.

88. Ibid., p. 2.

89. Ibid., p. 2.

90. Ibid., p. 4.

91. Minutes of the Working Party of the Constitution of the Federation 1957, CO 941/86 (E/14).

92. Sixteenth meeting of the Working Party, 2 April 1957, pp. 1-4, CO 941/85. See also Note of discussion 
The Alliance was taken aback by the boycott. High Commissioner MacGillivray, too, was alarmed by the actions of the rulers' representatives and quickly sought to find a compromise between the parties. ${ }^{93}$ He suggested that as a compromise it should be proposed to the rulers' representatives that the provisions of Part III of the Fifth Schedule of the Federation Agreement, which provided the state with additional allocations for certain contingencies after approval from the High Commissioner, be included in the new constitution. ${ }^{94}$ The Alliance agreed and this offer was conveyed to the rulers' representatives immediately by the High Commissioner. The rulers' representatives, as a result of the compromise offered by the Alliance, returned to the discussions in the following Working Party meeting. ${ }^{95}$ This was a significant victory by the rulers to strengthen the financial autonomy of the states.

Further discussions ensued on other areas of the financial provisions and more compromises were needed. The rulers' representatives reiterated their proposal that 25 percent of national revenue from customs duties and excise should be given to the states in order to provide greater financial autonomy. They pointed out that Johore, for example, received less from the percentage of petrol duty because of its proximity to duty-free Singapore. ${ }^{96}$ In addition, the states were not keen to continue with the present system whereby development grants were only paid to certain states on an ad-hoc basis as they felt this resulted in arguments each year. ${ }^{97}$ The rulers' representatives offered a new proposal to resolve the impasse. They suggested that there should be a "block allocation" to the states annually based on a sum of dollars per head of population of the state; and a sum per mile of the state roads. ${ }^{98}$ The Alliance representatives, however, felt the federation government could not delegate to the state governments its responsibility to ensure that the states received a fair share of the allocations under the federal system. ${ }^{99}$ They argued that under the new proposals there was a danger that the undeveloped states such as Kelantan, Pahang, Perlis and Terengganu would no longer receive the development grant. ${ }^{100}$

The rulers' representatives then suggested that a "Reserve Fund" could be

in Conference of Rulers, 10 April 1957, CO 491/86.

93. Minutes of Seventeenth meeting of the Working Party, 9 April 1957, p. 1, CO 941/85.

94. Seventeenth meeting of the Working Party, 9 April 1957, p. 1, CO 941/85. The provisions of Part III (paragraphs 2, 3, 7 and 8) of the Fifth Schedule of the Federation Agreement allowed the states additional funds, after consultation with the Financial Secretary and the High Commissioner, to cover special circumstances, to provide for additional appointments in the state civil service, to make use of savings on expenditure as supplementary expenditure, and to receive special allocations for expenditure for "unforeseen circumstances." See Fifth Schedule of Federation Agreement.

95. Minutes of Eighteenth meeting of the Working Party, 16 April 1957, p. 1.

96. CO 941/85, Minutes of Eighteenth meeting of the Working Party, 16 April 1957, p. 4, CO 941/85.

97. Ibid., p. 4.

98. Ibid., p. 4.

99. Ibid., p. 5.

100. Ibid., p. 4. 
created to assist states facing financial difficulties. ${ }^{101}$ If the proposals were accepted in principle, they noted, it would not be too difficult to work out a formula for the allocation of funds to the states based on a percentage basis. ${ }^{102}$ If this was agreed the states would give up the percentage of petrol import duty, the development grant, the transitional grant and the currency surplus (on which they were earlier adamant). ${ }^{103}$ The states were also willing to forego their proposal that they should be entitled to raise new taxes if they were given the grants as of right contained in their new proposals. ${ }^{104}$ MacGillivray felt that the new proposals of the rulers' representatives were "too rigid" and expected some states to suffer. ${ }^{105}$ He suggested instead that a percentage of the capitation grant could be paid into a reserve fund which could be used to assist the undeveloped states as well as be used for development in general. ${ }^{106}$ After further discussion, it was agreed that there should be a capitation grant formulated along the lines proposed by the rulers' representatives. ${ }^{107}$ The meeting also agreed that there should be a grant to meet the cost of maintenance of state roads and that a portion of the annual capitation grant should be set aside in a reserve fund for the states. ${ }^{108}$ This brought to a close the very difficult and complex discussions on the finance relations between the Alliance government and the states. The rulers fought hard to ensure that the states received adequate and guaranteed allocations annually to meet their expenses in order to ensure a greater degree of financial autonomy. The efforts of the rulers clearly achieved this goal.

\section{Conclusion}

The discussion above shows clearly that the rulers fought back strongly during the constitutional deliberations to defend their position and privileges as constitutional monarchs and the rights of the states to greater financial autonomy. They were clearly not playing second fiddle in the constitutional negotiations. While accepting their roles as constitutional monarchs under the new federal constitution, the rulers redefined the parameters of the institution of constitutional monarchy than originally provided in the Reid draft constitution. The Conference of Rulers, as a result of the rulers' submissions, gained greater prestige and powers than provided under the draft constitution. Under these changes the Rulers would be consulted on

101. Ibid., p. 5.

102. Ibid., p. 5.

103. Ibid., p. 5.

104. Ibid., p. 6.

105. Minutes of Twentieth of the Working Party, 18 April 1957, p. 2, CO 941/87.

106. Ibid., p. 2.

107. Minutes of Twentieth of the Working Party, 18 April 1957, p. 2, CO 941/87. Minutes of the Twentysecond meeting of the Working Party, 27 April 1957, pp. 2-3, CO 941/87. The rate of the capitation was eventually agreed at the Twenty-second meeting of the Working Party on 27 April 1957.

108. Minutes of Twentieth meeting of the Working Party, 18 April 1957, p. 2, CO 941/87. 
constitutional changes to the position and privileges of the rulers, territorial borders and matters relating to the Muslim religion and Malay customs. Equally significant, the rulers were able to secure greater financial guarantees to the states in terms of annual federal grants in the constitution. The states as a result of the efforts of the rulers' representatives were able to secure, as of right, annually the capitation grant and road maintenance grant. In addition, the federal constitution provided for the states to receive a portion of the export duties on minerals such as tin and enabled them to retain any surpluses remaining from the annual budgets. The institution of constitutional monarch in Malaya thus emerged from the constitutional deliberations considerably stronger and more influential than that envisaged by the Alliance and the Reid commission.

\section{Primary records}

The primary constitutional records of the Reid constitutional commission (19561957) are contained in the Colonial Office (CO) series CO 889/1-6. The minutes of the meetings of the Working Party which reviewed the Reid Commission draft constitution are contained in CO 941/85, CO 941/86 and CO 941/87. Both these constitutional records are deposited at The National Archives of Britain (TNA) in Kew, London. 
